\title{
Re-Evaluasi Proses Penyelesaian Pelanggaran Hak Asasi Manusia
}

\author{
Muhammad Arief \\ Fakultas Hukum, Universitas Muslim Indonesia \\ Koresponden, Email: moh.arif.fh@umi.ac.id
}

\begin{abstract}
ABSTRAK
Tujuan Penelitian menganalisis proses penyelesaian pelanggaran Hak Asasi Manusia (HAM) berat pada Persitiwa Trisaksi oelh Kejaksanaan Agung Republik Indonesia. Metode Penelitian yang digunakan adalah metode penelitian hukum. Normative dengan pendekatan kualitatif yang diuraikan secara deskriptif. Hasil peneltian menunjukan bahwa pelanggaran HAM berat pada peristiwa penanganan demonstrasi di Kampus Universitas Trisakti pada tahun 1998, oleh aparat keamanan; sehingga menyebabkan tewasnya empat orang mahasiswa dan ratusan lainnya luka. Komnas HAM telah melakukan (investigasi) penyelidikan terhadap peristiwa tersebut, dan laporan Komnas HAM menyimpulkan telah terjadi pelanggaran HAM berat atas insiden tersebut. Hasil penyelidikan tersebut telah dilaporankn Komnas HAM, dan berkas laporan tersebut telah diserahkan kepada Jaksa Agung; tetapi sampai saat ini ( \pm 18 tahun) Jaksa Agung belum memproses ke tingkat peneyidikan dan penuntutan. Alasan Jaksa Agung, berkaitan dengan hal-hal teknis yuridis, yang oleh publik dianggap tidak relevan dengan substansi kasus/masalah. Tetapi intinya aspek politis dan non yudisial lebih mengitari kasus-kasus tersebut.
\end{abstract}

Kata Kunci: Hak Asasi Manusia, Pelanggaran Berat, Peristiwa Trisakti

\begin{abstract}
The purpose of this research is to analyze the process of resolving gross violations of human rights (HAM) at the Trisaksi event by the Supreme Court of the Republic of Indonesia. The research method used is legal research methods. Normative with a qualitative approach described descriptively. The research results show that gross human rights violations during the handling of demonstrations at the Trisakti University Campus in 1998, by security forces; causing the death offour students and hundreds of others injured. Komnas HAM has conducted (investigated) investigations into the incident, and the Komnas HAM report concludes that gross human rights violations have occurred in the incident. The results of the investigation have been reported by Komnas HAM, and the report files have been submitted to the Attorney General; but until now ( \pm 18 years) the Attorney General has not yet proceeded to the level of investigation and prosecution. The Attorney General's reasons relate to juridical technical matters which the public deems irrelevant to the substance of the case / problem. But in essence, the political and non-judicial aspects surround these cases.
\end{abstract}

Keywords: Human Rights, Serious Violations, Trisakti Events 


\section{PENDAHULUAN}

Setiap negara memiliki kewajiban untuk menjamin dan menghormati hak asasi manusia, melindungi dan menegakkannya di negara masing-masing. Kewajiban ini tidak saja bersifat positif yaitu untuk ditegakkan atau diimpelementasikan. Dalam hal pengimpelementasian ini, terutama terhadap hak-hak asasi yang bersifat universal dan memiliki keberlakuan universal sebagaimana yang dirumuskan dalam deklarasi hak-hak asasi manusia. Oleh karena itu sebagaimana ditegaskan dalam Mukadimah Deklarasi Universal Hak Asasi Manusia/DUHAM, HAM perlu dilindungi dengan merumuskannya dalam instrumen hukum agar orang tidak akan terpaksa memilih pemberontakan sebagai usaha terakhir guna menentang kezaliman dan penindasan sebagaimana ditunjukan dalam sejarah HAM itu (Kusniati, 2011).

Secara historis, kemunculan Hak Asasi Manusia (HAM) adalah proses pembelaan kepada masyarakat atas tindakan sewenang-wenangan yang dilakukan oleh negara dan juga karena tidak seimbangnya posisi negara dengan masyarakat. Negara selalu menjadi pihak yang kuat karena mempunyai wewenang dan kekuasaan sedangkan masyarakat dalam posisi lemah atau dilemahkan karena tidak mempunyai wewenang apapun, apalagi kekuasaan (Haling, et.al, 2018). Di Indonesia, isu HAM mulai menjadi topik hangat pada zama pasca reformasi tahun 1998 (Darmawan, 2014). Pasca era reformasi, dengan periode kritis ketika hak asasi manusia dielaborasi secara rinci di dalam proses amandemen konstitusi Indonesia. Pada level struktural, hingga saat ini Indonesia telah pula menyatakan komitmen normatifnya untuk terikat pada sepuluh dari tiga belas perjanjian internasional kunci yang merumuskan norma (law making) hak asasi manusia (Citrawan, 2017).

Pada saat bergulirnya gerakan reformasi tahun 1998, yang digerakkan oleh para aktifis gerakan mahasiswa, dari berbagai kampus dalam rangka menumbangkan regim Orde Baru, berbagai peristiwa kekerasan terjadi seiring dengan gerakan reformasi tersebut. Gerakan massa (people power) tersebut melakukan demonstrasi selama berhari-hari di ibukota Jakarta kemudian disertai dengan kota-kota besar lain lain di seluruh Indonesia, pada akhirnya memaksa Presiden Soeharto berhenti dari jabatan pada tanggal 21 Mei 1998. Sekalipun gerakan demonatrasi itu berhasil menumbangkan regim Soeharto, tetapi sering dengan berjalannya gerakan protes dan demontrasi itu juga telah melahirkan berbagai kekerasa dan ketegangan anata para mahasiswa dengan aparat negara dalam hal ini tentara dan polisi.

Salah satu kejadian kekerasan yang terjadi tersebut adalah kejadian kekerasan antara aparat negara tentara dan polisi berhadap-hadapan dengan para demonstran mahasiswa di kampus Universitas Tri Sakti pada tanggal 12 Mei 1998. Kekerasan tersebut membuat tewasnya 4 orang mahasiswa Universitas Tri Sakti dan sejumlah mahasiswa lainnya luka-luka baik berat maupun ringan. Tewasnya dan luka-luka para mahasiswa tersebut karena di duga ditembaki oleh para penembak jitu (sniper) (Hardianti \& Rahayu, 2016).

Gerakan mahasiswa pada 1998 dapat disebut sebagai gerakan yang menjadi pelopor terjadinya sebuah perubahan sosial di Indonesia. Gerakan ini didukung oleh kondisi sosial masyarakat yang merasa bernasib sama yaitu kesamaan rasa tertindas oleh pemerintah Orde Baru hingga berujung pada kemarahan masyarakat pada pemerintah. Ada berbagai faktor yang mendorong mahasiswa melakukan aksi protes ini seperti, Soeharto yang melakukan penyalahgunaan wewenang, krisis moneter yang melanda kawasan Asia termasuk Indonesia, penindasan yang dirasakan oleh mahasiswa yang haknya dalam menyuarakan pendapat dibuat bungkam oleh pemerintah, dan Tragedi Trisakti yang paling memicu semangat para 
mahasiswa untuk terus melakukan aksi guna menegakkan keadilan (Septiana Puspita \& Liana, 2019).

Peristiwa ini disinyalir sebagai telah terjadi pelanggaran HAM berat oleh aparatur negara. Komnas HAM telah melakukan penyelidikan terhadap kasus tersebut. Dan hasilnya telah diserahkan kepada Kejaksaan Agung untuk ditindaklanjuti proses hukumnya dengan melakukan penyidikan dan dan penuntutan tetapi sampai kurang lebih 20 tahun kasus ini belum ada tindak lanjut dan kejelasannya. Komnas HAM telah beberapa kali mempertanyakan kasus ini tapi jawaban masih belum memuaskan. Seakan digantung tanpa ada kejelasan.

Dalam proses hukumnya, Kejaksaan Agung mengatakan, kasus ini bisa ditindaklanjuti jika ada rekomendasi dari DPR ke Presiden. Karena belum ada rekomendasi, maka Kejaksaan Agung mengembalikan berkas penyelidikan ke Komnas HAM. Dalih lainnya, Kejaksaan Agung menganggap kasus penembakan Trisakti sudah diputus oleh Pengadilan Militer pada 1999, sehingga tidak dapat diadili untuk kedua kalinya. Namun belakangan, Kejaksaan Agung beralasan kasus ini tidak dapat ditindaklanjuti karena DPR sudah memutuskan, bahwa tidak ditemukan pelanggaran HAM berat. Bahkan Jaksa Agung menyatakan bahwa penyelesaian kasus-kasus pelanggaran HAM berat di Indonesia termasuk dalam peristiwa Semanggi atau Trisakti akan diselesaiakan dengan cara non hukum, yakni dengan membentuk komisi kebenaran dan rekonsiliasi (KKR). Hal tersebut juga di kuatkan oleh Menkopolhukkam Wiranto, "bahwa pemerintah berkeingin menyelesaikan kasus-kasus pelanggaran HAM berat dengan cara non hukum.

\section{METODE PENELITIAN}

Penelitian ini menggunakan penelitian hukum normative dengan pendekatan kualitatif melalui analisis peraturan perundang-undangan terkait proses penyelesaian pelanggaran HAM Berat pada kasus Trisaksi. Penelitian ini menganalisa kinerja aparat penegak hukum, khususnya Kejaksaan Agung dalam upaya penyelesaian kasus tersebut. Adapun data utamanya adalah data hukum primer, berupa peraturan perundang-undangan yang berkaitan dengan penelitian yang dilakukan. Sumber bahan hukum yakni, kajian literatur, pendapat ahli, dan studi kasus. Kajian literatur merujuk pada peraturan perundangundangan, buku, jurnal, hasil penelitian, dan sebagainya. Selanjutnya analisis dilakukan dengan metode analisis kualitatif dengan penguraian secara deskriptif (pemaparan).

\section{PEMBAHASAN}

\section{A. Kilas Balik Peristiwa Trisaksi}

Tragedi Trisakti adalah peristiwa penembakan, pada tanggal 12 Mei 1998, terhadap mahasiswa pada saat demonstrasi menuntut Soeharto turun dari jabatannya. Kejadian ini menewaskan empat mahasiswa Universitas Trisakti di Jakarta,Indonesia serta puluhan lainnya luka. Mereka yang tewas adalah Elang Mulia Lesmana (1978-1998), Heri Hertanto (1977 - 1998), Hafidin Royan (1976 - 1998), dan Hendriawan Sie (1975 - 1998). Mereka tewas tertembak di dalam kampus, terkena peluru tajam di tempat-tempat vital seperti kepala, tenggorokan, dan dada. Peristiwa penembakan empat mahasiswa Universitas Trisakti ini juga digambarkan 
dengan detail dan akurat oleh seorang penulis sastra dan jurnalis, Anggie Dwi Widowati dalam karyanya berjudul Langit Merah Jakarta (Hutahean, 2014).

Ekonomi Indonesia mulai goyah pada awal 1998, yang terpengaruh oleh krisis finansial Asia sepanjang 1997-1999. Mahasiswa pun melakukan aksi demonstrasi besar-besaran ke Gedung Nusantara, termasuk mahasiswa Universitas Trisakti. Mereka melakukan aksi damai dari kampus Trisakti menuju Gedung Nusantara pada pukul 12.30. Namun aksi mereka dihambat oleh blokade dari Polri dan militer datang kemudian. Beberapa mahasiswa mencoba bernegosiasi dengan pihak Polri. Akhirnya, pada pukul 17.15, para mahasiswa bergerak mundur, diikuti bergerak majunya aparat keamanan. Aparat keamanan pun mulai menembakkan peluru ke arah mahasiswa. Para mahasiswa panik dan bercerai berai, sebagian besar berlindung di Universitas Trisakti. Namun aparat keamanan terus melakukan penembakan. Korban pun berjatuhan, dan dilarikan ke RS Sumber Waras.

Satuan pengamanan yang berada di lokasi pada saat itu adalah Brimob, Batalyon Kavaleri 9, Batalyon Infanteri 203, Artileri Pertahanan Udara Kostrad, Batalyon Infanteri 202, Pasukan Anti Huru Hara Kodam serta Pasukan Bermotor. Mereka dilengkapi dengan tameng, gas air mata, Steyr, dan SS-1. Pada pukul 20.oo dipastikan empat orang mahasiswa tewas tertembak dan satu orang dalam keadaan kritis. Meskipun pihak aparat keamanan membantah telah menggunakan peluru tajam, hasil otopsi menunjukkan kematian disebabkan peluru tajam. Hasil sementara diprediksi peluru tersebut hasil pantulan dari tanah peluru tajam untuk tembakan peringatan.

\section{B. Upaya Penegakkan Hukum Penyelesaian Kasus Trisaksi}

Setelah peristiwa tersebut, dengan alasan telah terjadi pelanggaran berat HAM yang sistematik dan meluas, keluarga korban dan mahasiswa tetap mendesak Komnas HAM untuk melakukan penyelidikan terhadap kasus ini. KPP HAM Trisakti, Semanggi I dan Semanggi II ini terbentuk pada tahun 2001. Namun, proses penyelidikan mengalami hambatan, antara lain kesulitan untuk mengakses informasi dari lembaga-lembaga negara maupun sikap tidak kooperatif institusi TNI dan Polri terhadap pemeriksaan anggotanya. Dalam laporannya, KPP HAM menyimpulkan bahwa dari bukti-bukti permulaan yang cukup telah terjadi pelanggaran berat HAM dalam peristiwa Trisakti, Semanggi I dan Semanggi II dengan 50 orang yang diduga tersangka. Hasil penyelidikan Komnas HAM diberikan kepada Kejaksaan Agung untuk segera dilakukan penyidikan sesuai UU No. 26 tahun 2000, pada April 2002.(Kontras: 2005, 2).

Namun berkas tersebut dikembalikan oleh Keajaksaan agung sampai tiga kali, untuk disempurnakan. Bahkan hasil peneyempurnaan yang ketiga kalinya ketika telah disampaikan ke Kejaksaan Agung sampai saat ini belum ditindaklanjuti pada tahap penyidikan dan penuntututan. Jaksa Agung mengembalikan berkas penyelidikan KPP (Komisi Penyidik Pelanggaran) HAM adalah pada 21 Mei 2002. Dalam surat pengembalian berkas tidak dicantumkan jangka waktu 30 hari untuk perbaikan sesuai petunjuk. Alasan pengembalian berkas tersebut adalah sebagai berikut : 
(1). BAP Komnas HAM atas tiga kasus tersebut hanya berupa transkip wawancara. Berita acara itu harus dibuat dalam setiap tindakan pemeriksaan saksi, penggeledahan, atau penangkapan. Semua harus dibuat BAP berdasarkan sumpah jabatan yang melakukannya. KPP HAM menjelaskan bahwa keterangan 40 saksi sipil yang digunakan KPP masih berbentuk wawancara tertulis dan bukan berita acara yang dapat digunakan sebagai bahan penyidikan.

(2). Jaksa Agung mempertanyakan mengenai Sumpah Jabatan sebagai Penyelidik, karena hasil kerja KPP HAM belum dapat dikategorikan sebagai penyelidikan, sebagaimana diatur dalam Pasal 102 ayat 3 dan Pasal 75 Kitab Undang-Undang Hukum Pidana (KUHP) serta pasal 19 ayat 1 UU No 26/200o tentang Pengadilan HAM. Tindakan kepolisian membuat berita acara pemeriksaan seseorang dilakukan oleh aparat polisi penyidik, bukan aparat polisi penyelidik. Polisi penyidik disumpah, polisi penyelidik tidak disumpah. Padahal pemeriksaan dilakukan dalam rangka menemukan tersangka. Fungsi polisi penyelidik sama dengan fungsi KPP selaku penyelidik yakni melakukan serangkaian tindakan untuk mengumpulkan keterangan guna memastikan ada tidaknya kejahatan. Hal ini secara tegas diatur dalam KUHAP.

(3). Pihak Jaksa Agung tetap meminta agar petunjuk dipenuhi oleh KOMNAS HAM. Jaksa Agung mencantumkan batas waktu 30 hari untuk perbaikan berkas penyelidikan selain kelengkapan tiga berkas tersebut, yaitu :

a. Jaksa Agung mempersoalkan saksi dan penyelidik yang harus disumpah, urgensi melakukan penyelidikan, kebangsaan para saksi dan tanda tangan peserta penulisan kata "Pro-Justicia" atau "Untuk Keadilan" disetiap halaman pertama pada bagian atas berkas penyelidikan.

b. Dilembar Ketiga angka III, Jaksa Agung mengingatkan bahwa kasus Trisakti, para terdakwa telah divonis bersalah oleh Mahkamah Militer Tinggi (Mahmilti) II di Jakarta. Kasus Semanggi I - II masih dalam proses Polisi Militer Komando Daerah Militer (Kodam). Sehingga perkara tersebut telah nebis in idem.(Alvira Metha Viricia: 2010: 3940)

Terhadap alasan Jaksa Agung mengembalikan berkas perkara kasus Trisakti dan Kasus semanggi I dan II, KontraS memberikan tanggapan sebagai berikut:

(1). Syarat formil; sumpah jabatan, syarat membuat berita acara, dilaksanakannya ketentuan Pasal 19 ayat (1) huruf g UU 26/200o, semua berita acara yang tidak memuat identitas lengkap subyek atau orang yang didengar sebagai saksi (Pasal 143 ayat (2) huruf a, Pasal 5 UU 26/200o; dan syarat materiil; agar dilakukan pemeriksaan terhadap saksi-saksi, baik dari militer, polisi dan lain-lain, serta diusahakan dokumen-dokumen relevan, agar dipelajari dan didalami implikasi hukum yang telah dilakukan dimaksud, sesuai dengan ketentuan Pasal 91 ayat (1) huruf e UU No.39/1999 serta dikaitkan dengan Pasal 42 ayat (1) huruf b dan Pasal 42 ayat (2) huruf b UU No.26/2000;

(2). Sumpah jabatan. Apakah benar menurut Undang-Undang yang berlaku, penyelidik atau penyelidik ad hoc harus disumpah sebelum melakukan penyelidikan? Kalau memang 
benar, lalu bagaimana dengan penyelidik dan penyelidik ad hoc yang pernah bekerja untuk tim ad hoc Komnas HAM sebelumnya?

Permintaan agar penyelidik KPP HAM TSS dan KPP HAM Mei 1998 disumpah adalah hal yang baru. Permintaan ini tidak pernah terjadi dalam pengalaman penyelidikan Komnas HAM sebelumnya, antara lain untuk KPP Timor-Timur, KP3T Tanjung Priok dan tim ad hoc penyelidik lainnya yang dibentuk Komnas HAM. Bahkan beberapa tim ad hoc (komisi penyelidik-KPP) terdahulu telah ditindaklanjuti Jaksa Agung hingga ke pengadilan. Proses penyelidikan berjalan tanpa pernah dipersoalkan karena sumpah jabatan.

Undang-Undang No. 26 tahun 2000 tentang Pengadilan HAM hanya mewajibkan sumpah jabatan kepada penyidik atau penyidik ad hoc. Misalnya kewajiban pengambilan sumpah sebelum menjalankan tugas hanya bagi Penyidik ad hoc sesuai Pasal 21 ayat (4), Penuntut Umum sesuai Pasal 23 ayat (3) dan Hakim sesuai Pasal 30. Sementara Kitab UndangundangHukum Acara Pidana juga hanya mengatur kewajiban membuat berita acara seperti diatur Pasal 75 KUHAP merupakan tugas Penyidik. Pasal 8 KUHAP berbunyi:

"Penyidik membuat berita acara tentang pelaksanaan tindakan sebagaimana dimaksud dalam pasal 75 dengan tidak mengurangi ketentuan lain dalam undang-undang ini.”

Dengan ketentuan diatas, maka yang semestinya membuat berita acara adalah Penyidik, bukan penyelidik. Dalam kasus pelanggaran HAM, Jaksa Agung adalah penyidik. KPP HAM atau Komnas HAM hanya selaku penyelidik. Jadi salah kaprah jika Jaksa Agung mempersoalkan pembuatan berita acara kepada Komnas HAM yang hanya penyelidik. Begitupula dengan sumpah jabatan. Pasal 121 KUHAP menyatakan:

"Penyidik atas kekuatan sumpah jabatannya segera membuat berita acara yang diberi tanggal dan memuat tindak pidana yang dipersangkakan, dengan menyebut waktu, tempat tinggal dari tersangka dan atau saksi, keterangan mereka, catatan mengenai akta dan atau benda serta segala sesuatu yang dianggap perlu untuk kepentingan penyelesaian perkara."

(3). Berita acara yang tidak memuat identitas lengkap subyek atau saksi. Jaksa Agung mempersoalkan tidak dicantumkannya identitas "kebangsaan" dari saksi atau orang yang didengar keterangannya oleh penyelidik. Jaksa Agung menunjuk Pasal 143 ayat (2) huruf a KUHAP. Ketentuan ini keliru, sebab sangat tidak memiliki relevansi juridis sehubungan dengan tugas Penyelidik. Pasal 143 ayat (2) adalah ketentuan yang mengatur tugas Penuntut Umum dalam membuat surat dakwaan. Dengan demikian, yang seharusnya melengkapi identitas subyek atau orang yang didengar sebagai saksi adalah Penuntut Umum bukan Penyelidik. Bukan KPP HAM. Lihat ketentuan Pasal 143 ayat (2) berbunyi: "Penuntut Umum membuat surat dakwaan yang diberi tanggal dan ditanda tangani serta berisi;

a. nama lengkap, tempat lahir, umur atau tanggal lahir, jenis kelamin, kebangsaan, tempat tinggal, agama dan pekerjaan tersangka;

b. uraian secara cermat, jelas dan lengkap mengenai tindak pidana yang didakwakan dengan menyebutkan waktu dan tempat tindak pidana itu dilakukan, 
Dalam merespon penyelidikan Komnas HAM, Jaksa Agung berada dalam kapasitas sebagai Penyidik, bukan Penuntut Umum. Dengan demikian ketentuan Pasal 143 ayat (2) diatas menjadi tidak relevan. Jika memang Jaksa Agung membutuhkan Pasal 143 ayat (2) dalam membuat surat dakwaan, Jaksa Agung dalam kapasitas sebagai Penuntut Umum harus meminta kepada Penyidik. Dan ini terlalu dini. Sebab Jaksa Agung belum bisa bertindak sebagai Penuntut Umum, bahkan belum sebagai Penyidik.

Selain itu, soal identitas "kebangsaan" seperti dimaksud Pasal 5 UU 26/200o, juga tidak masuk akal. Pasal 5 UU 26/200o hanya untuk pelanggaran HAM berat yang dilakukan diluar batas teritorial Indonesia, yang dilakukan oleh warga negara Indonesia. Sedangkan peristiwa Trisakti, Semanggi dan tragedi Mei 1998 terjadi didalam wilayah territorial negara Indonesia. Simak baik-baik Pasal 5 UU 26 tahun 2000 tentang Pengadilan HAM :

"Pengadilan HAM berwenang juga memeriksa dan memutus perkara pelanggaran hak asasi manusia yang berat, yang dilakukan diluar batas territorial wilayah Negara Republik Indonesia."

Penjelasan pasal tersebut berbunyi :"Ketentuan dalam pasal ini, dimaksudkan untuk melindungi warga negara Indonesia yang melakukan pelanggaran HAM yang berat yang diletakkan diluar batas territorial, dalam arti tetap dihukum sesuai dengan Undangundang tentang Pengadilan HAM ini."

(4). Pemeriksaan saksi, militer, polisi dan dokumen-dokumen relevan. Dari seluruh alasan pengembalian berkas, pihak Jaksa Agung ingin menunjukkan ketelitiannya terhadap ketentuan hukum yang berlaku. Tapi yang terjadi justru sebaliknya. Dalam hal pemeriksaan misalnya, istilah "pemeriksaan terhadap saksi-saksi" sehubungan dengan kerja Komnas HAM atau Penyelidik tidak dikenal dalam UU 26/200o. Penyelidik Komnas HAM hanya berwenang memanggil saksi untuk diminta dan didengar keterangannya, dan memanggil pihak terkait memberi keterangan tertulis atau menyerahkan dokumen yang diperlukan sesuai aslinya. Begitu pula KUHAP. Tidak satupun ketentuan KUHAP menyebut istilah pemeriksaan saksi-saksi dalam kaitan tindakan penyelidik. Lihat kewenangan Penyelidik pada Pasal 5 ayat (1) dan ayat (2) KUHAP.

Selain itu sulit bagi Komnas HAM untuk memanggil kembali saksi baik militer maupun polisi yang sudah jelas menolak. Justru Jaksa Agung harus bertindak atas penolakan itu. Yaitu dengan memberi perintah tertulis kepada penyelidik Komnas HAM mengenai hal itu.

- Pasal 91 ayat (1) huruf e UU No. 39/1999 dan Nebis in idem. Selengkapnya, Pasal 91 ayat (1) UU No. 39 tahun 1999, berbunyi:

(1) Pemeriksaan atas pengaduan kepada Komnas HAM tidak dilakukan atau dihentikan apabila:

a. tidak memiliki bukti awal yang memadai;

b. materi pengaduan bukan masalah pelanggaran HAM

c. pengaduan diajukan dengan itikad buruk atau ternyata tidak ada kesungguhan dari pengadu;

d. terdapat upaya hokum yang lebih efektif bagi penyelesaian materi pengaduan; atau 
e. sedang berlangsung penyelesaian melalui upaya hokum yang tersedia sesuai dengan ketentuan peraturan perundang-undangan.

(2) Mekanisme pelaksanaan kewenangan untuk tidak melakukan atau menghentikan pemeriksaan sebagaimana dimaksud dalam ayat (1) ditetapkan dengan Peraturan Tata Tertib Komnas HAM.

Pemeriksaan atas pengaduan berarti berkenaan dengan tindak pidana aduan. Artinya Pasal diatas mengatur soal pemeriksaan atas pengaduan. Penembakan mahasiswa dan berbagai bentuk tindak kejahatan pada tragedi Mei 1998 bukan delik aduan. Sehingga Komnas HAM wajib menyelidikinya. Bedakan antara laporan dan pengaduan seperti disebut Pasal 1 butir 24 dan butir 25 KUHAP2o. Dengan demikian, Pasal 91 ayat (1) UU No. 39 tahun 1999 tentang HAM, tidak relevan. Jadi tidak ada implikasi hukumnya.Alasan Jaksa Agung dengan menggunakan pasal tersebut dengan mengkaitkannya pada asas hukum nebis in idem, perlu diteliti lebih jauh. Pihak Jaksa Agung menyampaikan salah satu alasan keraguan Jaksa Agung untuk menindaklanjuti kasus ini adalah nebis in idem.Pendapat ini jelas keliru, sebab secara yuridis prinsip hukum nebis in idem itu hanya bisa berlaku kalau peristiwa yang diadili sudah memperoleh kekuatan hukum yang tetap atau in kracht van gewijsde.

Perkara penembakan mahasiswa di kampus Trisakti memang pernah dibawa ke Mahmakah Militer. Tetapi yang diperiksa mahkamah militer itu bukan delik pidana pembunuhan atau penembakan yang berakibat pembunuhan. Tapi menyangkut masalah internal militer, sekadar kesalahan prosedur. Kalaupun pada tahun 2001 juga digelar Mahkamah Militer untuk peristiwa pembunuhannya, cenderung untuk menghindari proses hukum yang baru dimulai Komnas HAM dengan membentuk tim penyelidik KPP HAM Trisakti, Semanggi I dan Semanggi I. Lagipula, putusan hakim itu belum memiliki kekuatan hukum yang tetap. Belum in kracht van gewijsde.

Pertanyaan lebih lanjutnya adalah apakah peristiwa Semanggi sudah dibawa ke pengadilan dan pelakunya diadili? Belum. Jadi belum ada satupun perkara itu yang diadili. Penembakan mahasiswa di kampus Atmajaya dan sekitar jembatan Semanggi I itu belum sempat disentuh. Salah seorang aktifis KontraS Usman Hamid mengikuti proses uji balistik di Kanada pada Mei 1999. Bukan saja terhadap proyektil peluru senjata dari peristiwa Trisakti tapi juga terhadap peristiwa Semanggi I.

Perlu diingat, yang seharusnya dikejar pertanggungjawaban pidananya atas peristiwa penembakan mahasiswa, warga sipil dan berbagai bentuk kekerasan dalam kerusuhan Mei 1998 bukanlah individu-individu prajurit TNI/POLRI yang berada di lapangan. Bukan orangorang yang hanya menerima dan melaksanakan perintah, melainkan tanggungjawab komandan atas tindak pidana yang dilakukan anak buah atau bawahan. (KontraS: 2005: 7-10)

\section{Faktor Penghambat Penyelesaian Kasus Trisaksi}

Faktor penghambat dalam penyelesaian kasus Trisakti, selain alasan teknis yuridis, tetapi yang paling mendasar adalah kemauan politik pemerintah. Dalam hal teknis yuridis misalnya:

\section{Undang-Undang}


Keberadaan UU Nomor .26 Tahun 2000 tentang Pengadilan HAM merupakan bukti bahwa Bangsa Indonesia berkehendak baik ( $\mathrm{goog}$ will) untuk menyelesaikan sendiri dugaan pelanggaran HAM melalui pengadilan HAM nasional (Halili, 2010). Namun, keberaadaan UU No. 26 Tahun 2000 mengandung kelemahan-kelemahan substansial. Pembuatan UU tersebut sebenarnya memiliki legitimasi politik yang kuat seiring dengan menguatnya konfigurasi politik di DPR hasil Pemilu 1999, termasuk menguatnya dukungan elemen-elemen demokrasi di luar Parlemen. Kemenangan kekuatan pro demokrasi di Pemilu 1999 tidak dengan sendirinya mampu memproduk hukumhukum responsive Mahfud, 2000).

Disisi lain, kendala pada undang-undang sendiri, bahwa kewenangan dalam proses peyelidikan oleh Komnas HAM dan penyidikan serta penuntutan dilakukan Jaksa Agung. Karena itu terjadi bolak-balik berkas antara kedua lembaga tersebut. Untuk menghindari bolak-baliknya berkas penyelidikan ada baiknya undang-undang memberikan kewenangan peneyelidikan, penyidikan dan dan penuntutan pada Komnas HAM saja. Instrumen perundang-undangan tentang HAM yang ada sekarang masih memberikan peluang bagi inkonsistensi penegakan hukum. Otoritas penyelidikan HAM yang dimiliki oleh Komnas HAM, misalnya, telah menjadi problem tersendiri manakala terdapat ketentuan dalam Pasal 43 Ayat (2) UU Nomor 26 Tahun 2000 tentang Pengadilan HAM yang menentukan agar Pengadilan HAM ad hoc dibentuk atas usul DPR RI.

Dua ketentuan tersebut ternyata telah melahirkan konflik kepentingan antara Komnas HAM yang merasa memiliki otoritas moral atas penegakan HAM dengan DPR yang sering dituduh sebagai lembaga yang sarat dengan pragmatisme politik. Situasi ini kemudian menjelma menjadi instrumentasi Komnas HAM oleh kelompok-kelompok yang tidak dapat mendesakkan kepentingan politiknya melalui agenda HAM kepada DPR.

Harus adanya penambahan terhadap tugas dan wewenang Komnas HAM yang hanya bukan hanya dapat melakukan penyelidikan terhadap kasus -kasus pelanggaran HAM yang berat sebagaimana diatur di dalam Pasal 18, 19, dan 20 UU 26 Tahun 200o. Sehingga dalam praktiknya, seringkali hasil penyelidikan yang dilakukan oleh Komnas HAM dipatahkan pihak Kejagung yang di dalam undang-undang ini bertindak sebagai penyidik dan penuntut umum. Pada akhirnya banyak kasus-kasus pelangaran HAM di Indonesia yang tidak sampai ke meja pengadilan dan hanya menjadi bahan dokumentasi Komnas HAM saja. Dengan adanya penambahan wewenang Komnas HAM diharapakan dapat menyeret para pelaku.

Penyebab lain dari kegagalan proses pengadilan ini adalah terkait dengan hukum acaranya. Meskipun Undang-undang Nomor 26 Tahun 2000 menjadi dasar dari suatu pengadilan hak asasi manusia yang merupakan perkara pidana yang luar biasa (extra ordinary crime), namun tidak dilengkapi dengan hukum acara yang luar biasa juga. Bahkan untuk hukum acara, merujuk pada hukum acara pidana biasa yang diatur melalui Kitab Undang-undang Hukum Acara Pidana (KUHAP). Hal ini menunjukkan ketidaksesuaian antara kriteria kejahatan dengan prosedur hukum dalam implementasinya (Hastuti, 2011).

\section{Penegak Hukum}

Pelanggaran HAM dimaknai sebagai sebagai setiap perbuatan seseorang atau kelompok orang termasuk aparat negara baik disengaja atau tidak disengaja, atau kelalaian yang secara melawan hukum mengurangi, menghalangi, membatasi dana tau mencabut hak asasi manusia seseorang atau kelompok orang yang diamin undang-undang, dan tidak mendapatkan proses penyelesaian hukum yang adil dan benar, berdasarkan mekanisme hukum yang berlaku Hambali, 2015). 
Dalam proses penegakan hukum pelaku pelanggaran HAM, seringkali kepentingan korban pada Pengadilan HAM seringkali dilanggar karena berbagai kepentingan politik. Demi menjaga akuntabilitas proses peradilan pada Pengadilan HAM, perlu keterlibatan masyarakat sebagai kontrol agar semakin meningkatkan keperdulian atas terselenggaranya peradilan yang adil (Dewi, 2016).

Pelanggaran terhadap HAM akan menimbulkan kewajiban bagi negara untuk melakukan pemulihan (Sujatmoko, 2016). Oleh karena itu, dibutuhkan penegakkan HAM yang membutuhkan aparat yang mandiri dan memiliki otoritas moral yang tinggi, sehingga penegakan hukum di Indonesia tidak tergelincir menjadi instrumen political retaliation dari pihak-pihak yang pernah mengalami represi politik pada masa lalu. Menjadi instrumen bagi kelompok tertentu untuk mendesakkan agenda politiknya. Sehingga harus diadakannya reformasi dalam tubuh aparat hukum dan peradilan Dan aparat harus mengadakan sosialisasi kepada masyarakat dan institusi-institusi peradilan tentang pengidentifikasian bentuk pelanggaran HAM seperti itu. Oleh karena itu, JPU yang mewakili kepentingan korban harus mempunyai pengetahuan dan kemampuan untuk menilai apakah suatu persidangan sudah memenuhi prinsip peradilan yang adil (Dewi, 2016).

\section{Faktor sarana dan fasilitas}

Adanya peradilan Hak Asasi Manusia di seluruh wilayah Indonesia sehingga penegakkan hukum dapat dijalankan sebagaimana mestinya Dukungan sarana dan prasarana yang belum memadai seringkali dijadikan alasan pembenar atas kinerja yang kurang baik atau produktivitas yang rendah. Rendahnya biaya operasional yang dialokasikan untuk penanganan kasus tidak jarang harus memaksa Jaksa untuk mengeluarkan dana dari kantong sendiri, dengan berbagai implikasinya (termasuk dana untuk mengirim surat panggilan atau menghadirkan saksi). Untuk itu perlu adanya perhatian darimerintah untukmenambah dana operasional dalam penegakan Hak Asasi Manusia.

\section{Faktor masyarakat}

Prinsip Partisipasi masyarakat mengharuskan bahwa aktor-aktor yang memiliki kewenangan membuka akses seluas-luasnya keterlibatan masyarakat dalam setiap tahapan pembentukan peraturan perundangundangan. Yang perlu digaris bawahi adalah titik tekannya bukan hanya pada seberapa jumlah dan jauh masyarakat telah terlibat dalam pembentukan peraturan perundang-undangan (Degrees of tokenism) tetapi seberapa jauh masyarakat dapat menentukan hasil akhir atau dampak dari peraturan perundang-undangan (Amir, 2014).

Di dalam ilmu hukum dikenal dengan adanya beberapa pendapat tentang kesadaran hukum. Diantara sekian banyak pendapat terdapat tentang kesadaran hukum. Diantara sekian banyak pendapat, terhadap suatu rumusan yang menyatakan bahwa sumber satu-satunya hukum dan kekuatan mengikatnya hukum adalah kesadaran hukum masyarakat. Dikatakan kemudian bahwa perasaan hukum dan keyakinan hukum individu di dalam masyarakat yang merupakan kesadaran hukum individu merupakan pangkal dari pada kesadaran hukum masyarakat. Selanjutnya pendapat tersebut menyatakan bahwa kesadaran-kesadaran hukum individu mengenai peristiwa tertentu (Usman, 2015).

Kesadaran hukum masyarakat menyangkut penegakan Hak Asasi Manusia pada dasarnya merupakan fundamen utama yang membangun efektivitas dan konsistensi penegakan Hak Asasi Manusia di Indonesia. Tetapi, masyarakat masih dipengaruhi oleh kecenderungan opini publik yang diciptakan media dalam mengangkat isu-isu pelanggaran Hak Asasi Manusia, 
sehingga tidak jarang kesadaran masyarakat justru dibentuk oleh opini publik yang diciptakan media.

Faktanya, kesadaran masyarakat justru sering digiring dan dibentuk oleh opini publik. Akibatnya, masyarakat sering kali larut ke dalam situasi trial by the press terhadap kasuskasus Hak Asasi Manusia yang diangkat oleh media. Akan dipastikan bahwa bila terdapat media-media yang cenderung bersikap partisan dalam menyoroti kasus-kasus Hak Asasi Manusia yang secara tidak langsung dapat membentuk persepsi yang tidak tepat tentang penegakan Hak Asasi Manusia. Untuk itu peranan dari Komnas HAM harus memberikan penyadaran akan artinya penegakan Hak Asasi Manusia dan pro aktif dalam melakukan pengawasan dalam penegakan Hak Asasi Manusia.

Hal lainnya adanya kebudayaan yang merupakan faktor non yuridis, dalam penegakkan HAM. Faktor kebudayaan dapat tercermin pada sensitivitas masyarakat dalam merespon kasuskasus HAM dan kemauan politik (political will) pemerintah dalam berkomitmen menjaga dan menegakkan HAM. Dalam kasus pelanggaran HAM untuk kasus Trisakti pemerintah terlihat lamban dan kurang sensivitasnya menuntaskan kasus tersebut.

\section{KESIMPULAN}

Ada dugaan terjadi pelanggaran HAM berat pada peristiwa penanganan demonstrasi di Kampus Universitas Trisakti pada tahun 1998, oleh aparat keamanan; sehingga menyebabkan tewasnya empat orang mahasiswa dan ratusan lainnya luka. Komnas HAM telah melakukan (investigasi) penyelidikan terhadap peristiwa tersebut, dan laporan Komnas HAM menyimpulkan telah terjadi pelanggaran HAM berat atas insiden tersebut. Hasil penyelidikan tersebut telah dilaporankn Komnas HAM, dan berkas laporan tersebut telah diserahkan kepada Jaksa Agung; tetapi sampai saat ini ( \pm 18 tahun) Jaksa Agung belum memproses ke tingkat peneyidikan dan penuntutan. Alasan Jaksa Agung, berkaitan dengan hal-hal teknis yuridis, yang oleh publik dianggap tidak relevan dengan substansi kasus/masalah. Tetapi intinya aspek politis dan non yudisial lebih mengitari kasus-kasus tersebut.

\section{SARAN}

1. Perlu adanya revisi terhadap UU nomor 26 tahun 2000 tentang Pengadilan HAM; dan Undang-Undang nomor 39 tahun 1999 tentang HAM; agar kewenangan penyelidikan, penyidikan dan penuntutan diberikan kepada Komnas HAM, mengingat pelanggaran HAM berat adalah (extra ordinary crime).

2. Perlu kesadaran HAM bagi aparat penegak hukum dan aparat pemerintah untuk menghargai dan melindungi HAM. Menginagt Indonesia adalah penganut negara hukum yang demokratis.

3. Khusus untuk kasus Trisakti (dan kasus-kasus pelanggaran HAM lainnya yang belum diselesaikan) Jaksa Agung hendaknya meneruskan proses penyidikan dan penuntutan sehingga keadilan dapat diberikan kepada para korban dan keluarga mereka

\section{DAFTAR PUSTAKA}

Amir, M. Y. D. L. (2014). Penguatan Tata Kelola Pemerintahan Yang Baik Dalam Pembentukan Peraturan Perundang-Undangan Sebagai Pilar Penegakan Hak Asasi Manusia Di Indonesia. Jurnal Ilmu Hukum Jambi, 5(2), 43280. 
Citrawan, H. (2017). Analisis Dampak Hak Asasi Manusia atas Regulasi: Sebuah Tinjauan Metodologi. Jurnal HAM, 8(1), 13-24.

Darmawan, J. (2014). Narasi Dramatis Berita Tragedi Trisakti 1998." Jurnal ILMU KOMUNIKASI, 11 (2), 11-35.

Dewi, Y. T. N. (2016). Hak Konstitusional Korban atas Pengadilan HAM yang Kompeten, Independen, dan Imparsial. Jurnal Konstitusi, 11(2), 256-275.

Hambali, A. (2015). Penyelesaian Pelanggaran Berat HAM Masa Lalu sebagai Pelaksanaan Pasal 28I ayat (2) UUD NRI Tahun 1945. Hasanuddin Law Review, 1(2), 266-281.

Hardianti, D., \& Rahayu, J. S. (2016). Tanggung Jawab Negara Menyelesaikan Kasus Pelanggaran Berat HAM Masa Lalu melalui Proses Rekonsiliasi di Indonesia. Diponegoro Law Journal, 5(3), 1-9.

Hastuti, L. (2011). Pengadilan Hak Asasi Manusia Sebagai Upaya Pertama dan Terakhir dalam Penyelesaian Pelanggaran Berat Hak Asasi Manusia di Tingkat Nasional. Jurnal Dinamika Hukum, 12(3), 395-406.

Halili, H. (2010). Pengadilan Hak Asasi Manusia dan pelanggengan budaya impunitas. Jurnal Civics: Media Kajian Kewarganegaraan, 7(1), 1-17.

Haling, S., Halim, P., Badruddin, S., \& Djanggih, H. (2018). Perlindungan Hak Asasi Anak Jalanan Dalam Bidang Pendidikan Menurut Hukum Nasional Dan Konvensi Internasional. Jurnal Hukum E Pembangunan, 48(2), 361-378.

Hutahaean, J. (2014). Dampak Kerusuhan Mei 1998 Terhadap Pengu-Saha Etnis Tionghoa Di Petukangan Jakarta Tahun 1998-2003. Journal of Indonesian History, 3(1), 27:33.

Kusniati, R. (2011). Sejarah Perlindungan Hak Hak Asasi Manusia dalam Kaitannya dengan Konsepsi Negara Hukum. INOVATIF| Jurnal Ilmu Hukum, 4(5), 79-92.

Mahfud, M. (200o). Politik Hukum Hak Asasi Manusia di Indonesia. Jurnal Hukum IUS QUIA IUSTUM, 7(14), 1-30.

Septy Puspita, L. A. Y. L. A., \& Liana, C. (2019). Gerakan Protes Mahasiswa Surabaya Terhadap Kekuasaan Orde Baru Pada Mei Tahun 1998 Di Surabaya. Avatara, 6(3), 1-10.

Sujatmoko, A. (2016). Hak atas pemulihan korban pelanggaran berat HAM di Indonesia dan kaitannya dengan prinsip tanggung jawab negara dalam hukum internasional. Padjadjaran Journal of Law, 3(2), 330-350.

Usman, A. H. (2015). Kesadaran Hukum masyarakat dan Pemerintah sebagai Faktor Tegaknya Negara Hukum di Indonesia. Jurnal Wawasan Yuridika, 3o(1), 26-53. 